\title{
Seed Bank from Abandoned Pastures in the Coastal Region of Paraná
}

\author{
Rosimeri de Oliveira Fragoso ${ }^{1}$, Antonio Aparecido Carpanezzi ${ }^{2}$, \\ Katia Christina Zuffellato-Ribas ${ }^{1}$, Henrique Soares Koehler ${ }^{1}$ \\ ${ }^{1}$ Universidade Federal do Paraná - UFPR, Curitiba/PR, Brasil \\ ${ }^{2}$ Embrapa Florestas, Colombo/PR, Brasil
}

\begin{abstract}
The aim of the present study was to evaluate the seed bank of three contiguous areas: pasture abandoned for ten years, with soil amended by partial beheading for two years at horizon A (area I); pasture identical to the previous example, but with recent mobilization of the topsoil (area II); area in the early stages of regeneration (area III). Field work was conducted in Morretes-PR, in an area of evergreen rain forest. In November 2013, seed bank samples were collected from ten points per area $(0.30 \times 0.30 \mathrm{~m})$ and at three depths $(0-3 \mathrm{~cm}+$ litter, 3.1 to $6.0 \mathrm{~cm}$ and 6.1 to $9.0 \mathrm{~cm})$. We obtained 25.151 seeds $\mathrm{m}^{-2}$, distributed between 85 species. The predominant life form was herbaceous (98\%), with the Cyperaceae family being the most abundant. In the seed banks of the three areas, only a few seeds from a restricted number of woody species were found, which therefore, represents a limited resource for forest restoration purposes.
\end{abstract}

Keywords: rain forest, inhibitory grasses, Urochloa. 


\section{INTRODUCTION}

Most regeneration of degraded ecosystems takes place in open areas that were abandoned or previously used as pasture (Sparovek et al., 2011). Grasses that grow aggressively modify the environment to such an extent that they impair seedling recruitment (Carpanezzi, 2005). In areas with a high degree of disturbance, seed rain contributes very little to forest succession (Myers \& Harms, 2009) and the soil's seed bank is the main regeneration mechanism (Vieira \& Pessoa, 2001).

A seed bank is defined as the stock of viable seeds present in the soil that accumulates over time through a dynamic input and output system, which varies according to species, consisting of transient and persistent banks (Thompson \& Grime, 1979). The persistent bank is made up of dormant seeds, while the transient bank consists of seeds that germinate one year or less after dispersion (Leal et al., 2013). Input into this system includes seed rain, and soil turnover mechanisms, while the main exit routes are germination, physiological death, and transfer to deeper soil layers (Martins \& Engel, 2007).

The rate of natural regeneration depends on factors such as availability of soil propagation material, the covering capacity of pioneer species, growth capacity and forage permanence, time of abandonment of the area, and soil disturbances (Cheung et al., 2009). In pastures with long periods of use under inadequate management practices, such as intensive use of heavy machinery, "supergrazing", and systematic herbicide application (Holl, 1999; Lanzanova et al., 2007), there is greater soil compaction and loss of surface layers, which reduces the amount of viable seeds in the seed bank and promotes unsustainable conditions for germination (Dias-Filho, 2006).

Studies into the influence of pastures on the availability of native and sub spontaneous species in the soil allow for the evaluation of the resilience potential of areas undergoing different types of disturbance (López-Toledo \& Martínez-Ramos, 2011). The use of such information to manipulate natural processes for the benefit of applied purposes is of great importance considering the continuation of the expansion of anthropic landscapes in the tropics (Chazdon et al., 2009).

The objective of this study was to evaluate the composition and density of the seed bank of three contiguous areas with grasses of the genus Urochloa - pasture abandoned for ten years, with soil amended by partial beheading for two years at horizon A (area I); pasture identical to the previous example, but with recent mobilization of the topsoil (area II); area undergoing early stages of regeneration (area III) - to verify its potential for restoration of the original forest (lowland evergreen rainforest).

\section{MATERIAL AND METHODS}

The experiment was conducted between November 2013 and July 2014. Seed bank samples were collected at the Experimental Station of Embrapa Florestas in Morretes, coastal Paraná region (latitude 2526’56”S and longitude $48^{\circ} 52^{\prime} 18^{\prime \prime} \mathrm{W}, 21 \mathrm{~m}$ altitude). The relief is flat, with Dystrophic Haplic Cambisol - CXbd (Oxic Dystrudepts) soil with moderate A horizon and clayey texture. The phytoecological region is classified as lowland evergreen rain forest (IBGE, 2012). The climate is Cfa, humid sub-tropical according to the Köppen classification, reaching mean temperatures close to $17^{\circ} \mathrm{C}$ in the coldest months and $24^{\circ} \mathrm{C}$ in the warmest months, with infrequent frosts and a tendency toward concentration of rainfall in the summer, but without a defined dry season (IAPAR, 2015). The present vegetation corresponds to abandoned pasture dominated by Urochloa grasses, popularly known as "brachiaria", with some small patches of spontaneous herbs. The surrounding region is predominantly rural, with farms intended for livestock and agriculture, as well as many natural forest fragments located about $500 \mathrm{~m}$ away.

Soil samples were collected in three similar topography areas: pasture abandoned for ten years, with soil amended by partial beheading for two years at horizon A (soil mechanization using a front blade to remove vegetation) (area I), pasture identical to the previous example, but presenting recent mobilization of the topsoil (area II), and an area in early stages of regeneration with high grasses, and without soil mobilization (area III). Samples from the seed bank were randomly collected from ten points per area (replicates), using a $0.30 \times 0.30 \mathrm{~m}$ template, at three depths: 0 to $3 \mathrm{~cm}+$ litter; 3.1 to $6.0 \mathrm{~cm} ; 6.1$ to $9.0 \mathrm{~cm}$.

The soil samples were placed in black plastic bags and taken to a greenhouse at Embrapa in Colombo-PR. Each sample was transferred to a plastic 
tray $(37.5 \times 26.5 \times 6.0 \mathrm{~cm})$ with perforations at the bottom, which contained $<2.5 \mathrm{~cm}$ of washed sand to enhance drainage. The trays with soil samples were distributed randomly on tables. To verify the presence of contaminated seeds, we used five trays containing only washed sand and commercial disinfested substrate. Contaminated seedlings were identified and excluded from density and floristic composition counts. Irrigation occurred four times a day for five min.

We evaluated seed banks weekly for eight months. The density and floristic composition of the seed banks were evaluated by counting and identifying emerged seedlings (Gross, 1990). Seedlings were discarded after counting. Unidentified seedlings were transplanted into $110 \mathrm{~cm}^{3}$ tubes filled with commercial substrate and sieved earth ( $1: 1 \mathrm{in} \mathrm{v} / \mathrm{v})$ for subsequent identification. Identification of botanical material was carried out using regional flora listings, specific bibliographies and specialists. Species names and their authors were confirmed with the Species List for Brazilian Flora (JBRJ, 2015).

The species were classified according to tree, shrub, and herbaceous life form (including grasses and creepers), as well as their origin (native and sub spontaneous) according to the Species List for Brazilian Flora (JBRJ, 2015). Within the sub spontaneous classification, we considered the so-called ruderal, cosmopolitan, and exotic invasive groups (Silva-Weber et al., 2012). They were also separated by the dispersal syndromes (zoochory, anemochory, and autochory) (Van der Pijl, 1982). In cases where the species could not be classified due to lack of information, the NC (unclassified) category was established. Subsequently, tree and shrub species were separated by successional categories of pioneer, early secondary, late secondary and climax species (Budowski, 1965). To compare the floristic composition of the seed bank of the three study areas, we calculated the Sorensen's similarity index (Brower \& Zar, 1984).

Seed bank samples from the three areas and three depths ( $3 \times 3$ arrangement) were evaluated according to a completely randomized design, with ten replicates per treatment, totaling thirty samples per area (total sample area of $2.7 \mathrm{~m}^{2}$ ). The homogeneity of the variances was verified through the Bartlett test and, later, the data was submitted to Analysis of Variance, in a split-plot design. The main plots corresponded to the three study areas and the subplots corresponded to the three soil depths. In situations of statistical significance $(\mathrm{p}<0.05)$, means of the variables were submitted to the Tukey test at $5 \%$ probability.

\section{RESULTS}

In total, we obtained 67,908 germinated seeds $\left(25,151\right.$ seeds $\left.\mathrm{m}^{-2}\right)$, corresponding to 85 species, of which only sixteen were classified as sub spontaneous (Table 1). The predominant plant life form was

Table 1. List of species found in the seed bank (per family, life form, seed dispersal and origin), in the three study areas: abandoned pasture with soil amended by the partial beheading of the horizon A (I), pasture identical to the previous example, but presenting mobilization of the topsoil (II) and area in early stages of regeneration (III).

\begin{tabular}{|c|c|c|c|c|c|c|c|c|c|}
\hline \multirow{3}{*}{ Family/ scientific name } & \multirow{3}{*}{ LF } & \multirow{3}{*}{ DS } & \multirow{3}{*}{ OR } & \multicolumn{6}{|c|}{ Number of individuals } \\
\hline & & & & \multicolumn{3}{|c|}{ Total } & \multicolumn{3}{|c|}{ by $\mathrm{m}^{2}$} \\
\hline & & & & I & II & III & I & II & III \\
\hline \multicolumn{10}{|l|}{ Anacardiaceae } \\
\hline Schinus terebinthifolius Raddi & Tre & Zoo & Nat & 1 & 0 & 0 & 1 & 0 & 0 \\
\hline \multicolumn{10}{|l|}{ Araliaceae } \\
\hline Hydrocotyle leucocephala Cham. \& Schltdl. & Her & Ane & Nat & 197 & 162 & 133 & 219 & 180 & 148 \\
\hline \multicolumn{10}{|l|}{ Asteraceae } \\
\hline Ageratum conyzoide L. & Her & Ane & Nat & 21 & 13 & 9 & 23 & 14 & 10 \\
\hline Baccharis caprariifolia DC. & Shr & Ane & Nat & 2 & 1 & 8 & 2 & 1 & 9 \\
\hline Baccharis trimera (Less) DC. & Her & Ane & Nat & 0 & 0 & 2 & 0 & 0 & 2 \\
\hline Centratherum punctatum Cass. & Her & Ane & Nat & 1 & 22 & 60 & 1 & 24 & 67 \\
\hline
\end{tabular}

$\mathrm{LF}=$ life form; $\mathrm{DS}=$ seed dispersal syndrome; $\mathrm{OR}=$ origin; Tre = tree; Shr = shrub; Her = herbaceous; Ane = anemochoric; Aut $=$ autochorous Zoo = zoochorous; $\mathrm{Nat}=$ native Sub = sub spontaneous $; \mathrm{nc}=$ not classified. 
Table 1. Continued...

\begin{tabular}{|c|c|c|c|c|c|c|c|c|c|}
\hline \multirow{3}{*}{ Family/ scientific name } & \multirow{3}{*}{ LF } & \multirow{3}{*}{ DS } & \multirow{3}{*}{ OR } & \multicolumn{6}{|c|}{ Number of individuals } \\
\hline & & & & \multicolumn{3}{|c|}{ Total } & \multicolumn{3}{|c|}{ by $\mathbf{m}^{2}$} \\
\hline & & & & I & II & III & I & II & III \\
\hline $\begin{array}{l}\text { Chromolaena maximilianii (Schrad. ex DC.) } \\
\text { R.M.King \& H.Rob. }\end{array}$ & Shr & Ane & Nat & 2 & 8 & 5 & 2 & 9 & 6 \\
\hline Eclipta alba (L.) HASSK & Her & Ane & Nat & 0 & 2 & 0 & 0 & 2 & 0 \\
\hline Erechtites hieracifolius (L.) Raf. ex DC. & Her & Ane & Nat & 58 & 38 & 44 & 64 & 42 & 49 \\
\hline Erechtites valerianifolius (Wolf) DC. & Her & Ane & Nat & 44 & 34 & 8 & 49 & 38 & 9 \\
\hline Gnaphalium pensylvanicum Willd. & Her & Ane & Nat & 67 & 76 & 117 & 74 & 84 & 130 \\
\hline Hypochaeris radicata $\mathrm{L}$. & Her & Ane & Sub & 1 & 5 & 2 & 1 & 6 & 2 \\
\hline Hyptis pectinata (L.) Poit. & Her & Aut & Nat & 1 & 1 & 38 & 1 & 1 & 42 \\
\hline Jaegeria hirta (Lag.) Less & Her & Zoo & Nat & 0 & 2 & 0 & 0 & 2 & 0 \\
\hline Mikania micrantha Kunthv & Her & Ane & Nat & 42 & 103 & 75 & 47 & 114 & 83 \\
\hline Senecio brasiliensis (Spreng.) Less. & Her & Ane & Nat & 3 & 6 & 4 & 3 & 7 & 4 \\
\hline Sonchus oleraceus L. & Her & Ane & Nat & 5 & 6 & 1 & 6 & 7 & 1 \\
\hline Sphagneticola trilobata (L.) Pruski & Her & Ane & Sub & 5 & 5 & 8 & 6 & 6 & 9 \\
\hline Vernonia beyrichii Less. & Shr & Ane & Nat & 42 & 24 & 100 & 47 & 27 & 111 \\
\hline Youngia japonica (L.) DC. & Her & Ane & Sub & 10 & 19 & 20 & 11 & 21 & 22 \\
\hline \multicolumn{10}{|l|}{ Begoniaceae } \\
\hline Begonia cucullata Willd. & Her & Ane & Nat & 42 & 1 & 2 & 47 & 1 & 2 \\
\hline
\end{tabular}

\section{Caryphyllaceae}

Drymaria cordata (L.) Willd. ex Roem. \& Schult. $\quad$ Her $\quad$ Zoo $\quad$ Sub $\quad \begin{array}{lllllll}18 & 15 & 3 & 20 & 17 & 3\end{array}$

\section{Commelinaceae}

Commelina diffusa Burm.

$\begin{array}{llllllll}\text { Her Zoo Nat } & 5 & 11 & 0 & 6 & 12 & 0\end{array}$

\section{Cucurbitaceae}

Melothria pendula $\mathrm{L}$.

Cyperaceae

Cyperus rotundus $\mathrm{L}$.

Kyllinga brevifolia Rottb.

Cyperus iria L.

Pycreus lanceolatus (Poir.) C.B.Clarke

Cyperus luzulae (L.) Retz.

Cyperus meyenianus Kunth

Eleocharis sellowiana Kunth

Fimbristylis miliacea (L.) Vahl.

Cyperus mundtii (Nees) Kunth

Pycreus flavescens (L.) Rchb.

\section{Fabaceae}

$\begin{array}{lccccccccc}\text { Mimosa bimucronata } \text { (DC.) Kuntze } & \text { Tre } & \text { Aut } & \text { Nat } & 0 & 2 & 28 & 0 & 2 & 31 \\ \text { Mimosa pudica } \text { L. } & \text { Her } & \text { Zoo } & \text { Nat } & 35 & 20 & 4 & 39 & 22 & 4 \\ \text { Aeschynomene rudis } \text { Benth. } & \text { Her } & \text { Aut } & \text { Nat } & 81 & 12 & 5 & 90 & 13 & 6 \\ \begin{array}{l}\text { Desmodium triflorum } \text { (L.) DC. } \\ \text { Hypericaceae }\end{array} & \text { Her } & \text { Zoo } & \text { Sub } & 26 & 13 & 13 & 29 & 14 & 14 \\ \begin{array}{l}\text { Hypericum brasiliense Choisy } \\ \text { Hypoxidaceae }\end{array} & \text { Her } & \text { Aut } & \text { Nat } & 14 & 2 & 4 & 16 & 2 & 4\end{array}$

$\mathrm{LF}=$ life form; $\mathrm{DS}=$ seed dispersal syndrome; $\mathrm{OR}=$ origin; Tre = tree; $\mathrm{Shr}=$ shrub; Her = herbaceous; Ane = anemochoric; Aut $=$ autochorous; $\mathrm{Zoo}=$ zoochorous; $\mathrm{Nat}=$ native; $\mathrm{Sub}=$ sub spontaneous; $\mathrm{nc}=$ not classified . 
Table 1. Continued...

\begin{tabular}{|c|c|c|c|c|c|c|c|c|c|}
\hline \multirow{3}{*}{ Family/ scientific name } & \multirow{3}{*}{ LF } & \multirow{3}{*}{ DS } & \multirow{3}{*}{ OR } & \multicolumn{6}{|c|}{ Number of individuals } \\
\hline & & & & \multicolumn{3}{|c|}{ Total } & \multicolumn{3}{|c|}{ by $\mathbf{m}^{2}$} \\
\hline & & & & I & II & III & I & II & III \\
\hline Hypoxis decumbens $\mathrm{L}$. & Her & Aut & Nat & 101 & 129 & 145 & 112 & 143 & 161 \\
\hline \multicolumn{10}{|l|}{ Iridaceae } \\
\hline Sisyrinchium sp. & Her & nc & Nat & 85 & 26 & 7 & 94 & 29 & 8 \\
\hline \multicolumn{10}{|l|}{ Lamiaceae } \\
\hline Hyptis brevipes Poit. & Her & Aut & Nat & 49 & 53 & 32 & 54 & 59 & 36 \\
\hline Mesosphaerum suaveolens (L.) Kuntze & Her & Aut & Nat & 35 & 10 & 20 & 39 & 11 & 22 \\
\hline \multicolumn{10}{|l|}{ Linderniaceae } \\
\hline Lindernia diffusa (L.) Wettst. & Her & Ane & Nat & 1 & 11 & 0 & 1 & 12 & 0 \\
\hline $\begin{array}{l}\text { Micranthemum umbrosum (Walter ex J.F.Gmel.) } \\
\text { S.F.Blake }\end{array}$ & Her & Ane & Nat & 2 & 3 & 34 & 2 & 3 & 38 \\
\hline Torenia thouarsii (Cham. \& Schltdl.) Kuntze & Her & nc & Nat & 0 & 4 & 3 & 0 & 4 & 3 \\
\hline \multicolumn{10}{|l|}{ Lythraceae } \\
\hline Cuphea carthagenensis (Jacq.) J.Macbr. & Her & Ane & Nat & 404 & 408 & 318 & 449 & 453 & 353 \\
\hline \multicolumn{10}{|l|}{ Malvaceae } \\
\hline Sida rhombifolia $\mathrm{L}$. & Her & Ane & Nat & 80 & 154 & 55 & 89 & 171 & 61 \\
\hline \multicolumn{10}{|l|}{ Mazaceae } \\
\hline Mazus pumilus (Burm.f.) Steenis & Her & nc & Sub & 5 & 19 & 2 & 6 & 21 & 2 \\
\hline \multicolumn{10}{|l|}{ Melastomataceae } \\
\hline Clidemia hirta (L.) D.Don & Her & Zoo & Nat & 157 & 109 & 479 & 174 & 121 & 532 \\
\hline Tibouchina cerastifolia Cogn. & Her & nc & Nat & 12 & 42 & 202 & 13 & 47 & 224 \\
\hline Tibouchina clinopodifolia Cogn. & Her & Ane & Nat & 27 & 2 & 26 & 30 & 2 & 29 \\
\hline \multicolumn{10}{|l|}{ Onagraceae } \\
\hline Ludwigia longifolia (DC.) H.Hara & Her & Aut & Nat & 701 & 1382 & 2 & 779 & 1536 & 2 \\
\hline Ludwigia octovalvis (Jacq.) P.H.Raven & Shr & Aut & Nat & 490 & 312 & 281 & 544 & 347 & 312 \\
\hline \multicolumn{10}{|l|}{ Oxalidaceae } \\
\hline Oxalis debilis Kunth & Her & Aut & Nat & 33 & 46 & 6 & 37 & 51 & 7 \\
\hline \multicolumn{10}{|l|}{ Phyllanthaceae } \\
\hline Phyllanthus niruri L. & Her & Aut & Nat & 36 & 138 & 18 & 40 & 153 & 20 \\
\hline Phyllanthus tenellus Roxb. & Her & Aut & Nat & 29 & 86 & 14 & 32 & 96 & 16 \\
\hline Phyllanthus urinaria $\mathrm{L}$. & Her & Aut & Nat & 29 & 786 & 1 & 32 & 873 & 1 \\
\hline \multicolumn{10}{|l|}{ Plantaginaceae } \\
\hline Scoparia dulcis L. & Her & Ane & Nat & 528 & 227 & 351 & 587 & 252 & 390 \\
\hline Stemodia vandellioides (Benth.) V.C.Souza & Her & Zoo & Nat & 53 & 120 & 2 & 59 & 133 & 2 \\
\hline \multicolumn{10}{|l|}{ Poaceae } \\
\hline Digitaria sp. & Her & Ane & Nat & 34 & 15 & 26 & 38 & 17 & 29 \\
\hline Eragrostis ciliaris (L.) R.Br. & Her & nc & Sub & 24 & 6 & 44 & 27 & 7 & 49 \\
\hline Poа аппиа $\mathrm{L}$. & Her & $\mathrm{nc}$ & Sub & 104 & 29 & 14 & 116 & 32 & 16 \\
\hline Paspalum conjugatum P.J.Bergius & Her & Ane & Nat & 6 & 2 & 19 & 7 & 2 & 21 \\
\hline Paspalum urvillei Steud. & Her & Ane & Nat & 8 & 0 & 9 & 9 & 0 & 10 \\
\hline Urochloa decumbens (Stapf) R.D.Webster & Her & Ane & Sub & 29 & 8 & 66 & 32 & 9 & 73 \\
\hline $\begin{array}{l}\text { Urochloa humidicola (Rendle) Morrone \& } \\
\text { Zuloaga }\end{array}$ & Her & Ane & Sub & 32 & 6 & 3 & 36 & 7 & 3 \\
\hline Urochloa subquadripara (Trin.) R.D.Webster & Her & Ane & Sub & 25 & 20 & 16 & 28 & 22 & 18 \\
\hline
\end{tabular}

$\mathrm{LF}=$ life form; $\mathrm{DS}=$ seed dispersal syndrome; $\mathrm{OR}=$ origin; Tre = tree; Shr = shrub; Her = herbaceous; Ane = anemochoric; Aut $=$ autochorous $; \mathrm{Zoo}=$ zoochorous; $\mathrm{Nat}=$ native; $\mathrm{Sub}=$ sub spontaneous; $\mathrm{nc}=$ not classified. 
Table 1. Continued...

\begin{tabular}{|c|c|c|c|c|c|c|c|c|c|}
\hline \multirow{3}{*}{ Family/ scientific name } & \multirow{3}{*}{ LF } & \multirow{3}{*}{ DS } & \multirow{3}{*}{ OR } & \multicolumn{6}{|c|}{ Number of individuals } \\
\hline & & & & \multicolumn{3}{|c|}{ Total } & \multicolumn{3}{|c|}{ by $\mathbf{m}^{2}$} \\
\hline & & & & I & II & III & I & II & III \\
\hline \multicolumn{10}{|l|}{ Polygonaceae } \\
\hline Polygonum persicaria $\mathrm{L}$. & Her & Aut & Sub & 0 & 7 & 0 & 0 & 8 & 0 \\
\hline \multicolumn{10}{|l|}{ Rubiaceae } \\
\hline Borreria latifolia (Aubl.) K.Schum. & Her & Aut & Nat & 1 & 0 & 0 & 1 & 0 & 0 \\
\hline $\begin{array}{l}\text { Borreria palustris (Cham. \& Schltdl.) Bacigalupo } \\
\text { \& E. L. Cabral. }\end{array}$ & Her & Aut & Nat & 509 & 414 & 290 & 566 & 460 & 322 \\
\hline $\begin{array}{l}\text { Diodia saponariifolia (Cham. \& Schltdl.) } \\
\text { K.Schum. }\end{array}$ & Her & Ane & Nat & 204 & 68 & 11 & 227 & 76 & 12 \\
\hline \multicolumn{10}{|l|}{ Scrophulariaceae } \\
\hline Veronica persica Poir. & Her & $\mathrm{nc}$ & Sub & 67 & 296 & 4 & 74 & 329 & 4 \\
\hline \multicolumn{10}{|l|}{ Solanaceae } \\
\hline Solanum americanum Mill. & Her & Zoo & Nat & 6 & 5 & 3 & 7 & 6 & 3 \\
\hline \multicolumn{10}{|l|}{ Umbelliferae } \\
\hline Centella asiatica (L.) Urban & Her & Zoo & Sub & 20 & 2 & 25 & 22 & 2 & 28 \\
\hline \multicolumn{10}{|l|}{ Urticaceae } \\
\hline Phenax sonneratii (Poir.) Wedd. & Her & $\mathrm{nc}$ & Nat & 68 & 66 & 1 & 76 & 73 & 1 \\
\hline Urtica dioica $\mathrm{L}$. & Her & Zoo & Sub & 0 & 0 & 1 & 0 & 0 & 1 \\
\hline \multicolumn{10}{|l|}{ Verbenaceae } \\
\hline Stachytarpheta cayennensis (Rich.) Vahl & Shr & Ane & Sub & 3 & 2 & 25 & 3 & 2 & 28 \\
\hline Verbena litoralis Kunth. & Her & Zoo & Nat & 298 & 84 & 35 & 331 & 93 & 39 \\
\hline \multicolumn{10}{|l|}{ Undetermined } \\
\hline Undetermined 1 & Her & $\mathrm{nc}$ & nc & 5 & 80 & 50 & 6 & 89 & 56 \\
\hline Undetermined 2 & Her & $\mathrm{nc}$ & nc & 9 & 4 & 7 & 10 & 4 & 8 \\
\hline Undetermined 3 & Her & nc & nc & 12 & 2 & 3 & 13 & 2 & 3 \\
\hline Undetermined 4 & Her & $\mathrm{nc}$ & nc & 0 & 1 & 1 & 0 & 1 & 1 \\
\hline Undetermined 5 & Her & $\mathrm{nc}$ & $\mathrm{nc}$ & 4 & 65 & 168 & 4 & 72 & 187 \\
\hline
\end{tabular}

LF = life form; DS = seed dispersal syndrome; $\mathrm{OR}=$ origin; Tre = tree; Shr = shrub; Her = herbaceous; Ane = anemochoric; Aut = autochorous; Zoo = zoochorous; Nat = native; Sub = sub spontaneous; $\mathrm{nc}=$ not classified.

herbaceous, representing $98 \%$ of the seedlings, with 66,572 seeds $\left(24,656\right.$ seeds $\left.\mathrm{m}^{-2}\right)$, the majority being native (96\%). Amongst these were 663 Poaceae grass seeds (24\% native) and 53,472 Cyperaceae seeds (100\% native). Cyperaceae represented $79 \%$ of the germinated individuals. Other life forms were 31 arboreal seeds and 1,305 shrub seeds, with all being classified as native pioneers.

The three areas (I, II, and III) presented similar species richness values: 76,78 , and 75 species, respectively, with floristic similarity ranging from 0.98 to 1.00 . Thirty families were identified, with Asteraceae (18) and Cyperaceae (10) showing greatest species richness (Table 1).
In relation to the dispersion syndrome, anemochory predominated in $46 \%$ of species. Autochory and zoochory were present in 20 and $17 \%$ of the species identified, respectively. Dispersal syndrome was undetermined for $17 \%$ of species (Table 1).

Area II had the highest density (Table 2) with 33,440 seeds $\mathrm{m}^{-2}$, including 2 tree seeds, 386 shrub seeds, 92 Poaceae seeds, 27,102 Cyperaceae seeds, and 5,858 other herbaceous seeds. Area I presented 30,748 seeds $\mathrm{m}^{-2}$, including 1 tree seed, 599 shrub seeds, 270 Poaceae seeds, 25,356 Cyperacea seeds, and 4,522 other herbaceous seeds. Area III presented a significantly lower density, with 11,266 seeds $\mathrm{m}^{-2}$, including 31 tree seeds, 466 shrub seeds, 211 Poaceae seeds, 7,536 Cyperaceae seeds, and 3,022 herbaceous. 
Table 2. Number of seeds $\mathrm{m}^{-2}$ in the seed bank of the three study areas: abandoned pasture with soil amended by the partial beheading of the horizon A (I), pasture identical to the previous example, but with mobilization of the topsoil (II) and area in early stages of regeneration (III). Three depths: 0-3 cm + litter (D1), 3.1-6 cm (D2) and $6.1-9 \mathrm{~cm}(\mathrm{D} 3)$.

\begin{tabular}{|c|c|c|c|c|c|c|c|c|c|}
\hline Depth /Area & & I & & & II & & & III & \\
\hline D1 & 15.198 & a & A & 9.853 & a & $\mathrm{AB}$ & 3.840 & a & $\mathrm{B}$ \\
\hline D2 & 8.949 & $\mathrm{ab}$ & $\mathrm{AB}$ & 12.342 & a & A & 3.351 & a & B \\
\hline D3 & 6.601 & $\mathrm{~b}$ & $\mathrm{AB}$ & 11.244 & a & A & 4.074 & a & $\mathrm{B}$ \\
\hline Total seeds in trays & & 27.673 & & & 30.096 & & & 10.139 & \\
\hline Total seeds $\mathrm{m}^{-2}$ & & 30.748 & & & 33.440 & & & 11.266 & \\
\hline \multicolumn{10}{|c|}{ CV $($ areas $)=67.13 \% /$ CV $($ depths $)=69.56 \%$} \\
\hline
\end{tabular}

$\mathrm{CV}=$ coefficient of variation. Averages followed by the same lower-case letter in the column and capital letter in the line did not differ by Tukey test at $5 \%$ probability.

\section{DISCUSSION}

A dominance of Cyperaceae and even herbaceous non-grass plants is commonly found in seed banks of abandoned pastures or fragmented environments (Wijdeven \& Kuzee, 2000; Miranda et al., 2014). Factors that contribute to this pattern include efficient dispersion mechanisms, reduced size, dormancy, and high seed production (Guimarães et al., 2014). The greater availability of space and luminosity favors the persistence of existing grasses and the emergence of other ruderal species with clear vegetative propagation, which can cover an area rapidly when pasture pressure is reduced (Vieira \& Pessoa, 2001).

Grass seeds, such as those belonging to the genus Urochloa, may also remain dormant and viable in the soil for several years (Miles \& Valle, 1998). This has been observed in some studies with seed banks (Severino et al., 2006; Ikeda et al., 2007), which have shown that Urochloa grasses are dominant and reduce the establishment of other plants. Despite this, there was a low density of Urochloa species from the seed banks in the three study areas, contradicting the predominance of these species' vegetative phase in the above-ground stratum, particularly in areas I and II (Table 1). This was because the dominant grass in the area, Urochloa subquadripara, is mainly propagated through vegetative means, and seed formation is infrequent (Kissmann \& Groth, 1997).

The seed density in each area was higher than that found in other studies carried out in pasture areas using the seedling emergence method, which ranged from 304 to $11,603 \mathrm{~m}^{-2}$ seeds in humid equatorial climate pasture (Silva \& Dias-Filho, 2001; Costa et al.,
2013), 241 to 1,998 seeds in tropical climate pastures (Costalonga et al., 2006; Calegari et al., 2013) and 3,792 to $6,312 \mathrm{~m}^{-2}$ seeds in humid subtropical climate (Chapla \& Campos, 2011). The seed density was also higher than that obtained in other environments, such as remnants of Mixed Ombrophilous Forest and Semideciduous Seasonal Forest, which presented 5,732 and $589 \mathrm{~m}^{-2}$ seeds, respectively (Martins \& Engel, 2007; Silva-Weber et al., 2012).

In tropical forests, the amount of seed in the soil is high at the beginning of succession, decreasing gradually (Chapla \& Campos, 2011), and the density of the seed bank increases considerably during the transition from forest to pasture, due to the presence of grasses and other herbaceous plants (Costalonga et al., 2006; Calegari et al., 2013). In fact, the species with the highest relative density were Cyperus brevifolius and Pycreus flavescens in areas I (45 and 24\%) and III (19 and 17\%) and Fimbristylis miliacea in area II (32\%) (Table 1). When disregarding the Cyperaceae family, density values fall significantly and fall within the range of commonly found values (around 5,153 $\mathrm{m}^{-2}$ seeds), considering the average of the three areas.

In areas I and II, despite the high seed density values, there was a low occurrence of shrubs and trees (Table 1). These densities are compatible with seed banks of anthropic landscapes (Wijdeven \& Kuzee, 2000), and the low occurrence of woody species in these areas may be related to the partial decapitation of horizon A. In pastures, higher soil compaction makes it difficult for seeds to penetrate, keeping them on the surface (Dias-Filho, 2006) and by removing the horizon A the seed stock of the bank is carried away.

The woody species found in areas I and II corresponded to only $1 \%$ and $2 \%$ of the total germinated seedlings, 
respectively. Even before removal of horizon A two years ago, the vegetation was dominated by Urochloa, although it was abandoned about ten years ago. In abandoned pastures, natural re-composition is quite slow due to modifications caused by aggressively growing grasses that inhibit natural regeneration (Costa et al., 2013). Therefore, although woody propagules are dispersed in pastures, there are no suitable sites for their germination, with some seeds that die and are no longer part of the seed bank (Holl, 1998).

Area III also presented a low number of woody seeds in the seed bank, making up only $4 \%$ of the germinated seedlings. Other studies, in similar environments, found a reduced stock of shrub-tree species and observed a predominance of herbaceous plants (Tres et al., 2007; Pereira et al., 2010; Miranda et al., 2014). Some authors point out that the results may be influenced by the method used - germination or direct counting - due to errors associated with seed dormancy and mortality (Pereira et al., 2010; Silva et al., 2011).

We found only two tree species, Mimosa bimucronata (areas II and III) and Schinus terebinthifolius (area I), both presenting pasture colonization potential. These species are often recommended for the recovery of degraded ecosystems due to their ease of installation and action as facilitators of natural regeneration (Carvalho, 1994; Bitencourt et al., 2007; Lorenzi, 2008). In area III, in the initial stage of regeneration, we observed a higher density of Mimosa bimucronata. This is due to the lower occupation of grasses in the above-ground stratum, which provides conditions for the installation of more selective and shrubby herbaceous plants and allows a greater establishment of arboreal individuals.

Ludwigia octovalvis and Vernonia beyrichii were among the shrub species found. Ludwigia octovalvis was mainly present in areas I and II. Characteristic of pastures, the Ludwigia species is considered to have the widest geographic distribution in Brazil (Lorenzi, 2008). Vernonia beyrichii is also present in these areas, and is also a pasture colonizer (Cheung et al., 2009). This species occurred in the area at the beginning of natural regeneration (area III), where it was found in the stratum above the ground forming dense clusters about $2.5 \mathrm{~m}$ high. This shrub is frequently found in the Atlantic Forest biome as the first species to establish after pasture abandonment, generally with a higher density than the other woody species (Scheer et al., 2009).
Higher numbers of Asteraceae and Cyperaceae species are commonly observed in field areas and anthropic regions. This has been attributed to the ease of colonizing open areas, clearings, or borders of fragments and the formation of persistent seed banks (formed by seeds that present dormancy) (Silva-Weber et al., 2012; Costa et al., 2013). These families were also the most frequent in floristic surveys of natural regeneration from other studies about abandoned pastures of the genus Urochloa (Silva \& Dias-Filho, 2001; Costa et al., 2013).

Despite the lower occupation of grasses in the above-ground stratum, the area III seed bank suffered significant influence from the herbaceous vegetation of adjacent pastures, which is reflected in the marked floristic similarity between the seed banks of the three areas. Some studies (Hall \& Swaine, 1980; Lopes et al., 2006) have found that floristic similarity between seed banks in nearby areas tends to be higher than that between seed bank and vegetation above the soil of the same area. This may be related to the limitation on seed dispersal caused by the proximity of pastures, which would not only affect the quantity of seeds that are dispersed, but also the diversity of species, which is restricted to the plants already present in the pasture (Harms et al., 2000). Likewise, there were no seeds in area II coming from nearby forest remnants, even with soil rotation and temporary removal of grasses, which could facilitate the deposition of seeds in the soil.

The limitation of seed rain may be due to reduced seed density, changes in fruiting seasonality, and absence of dispersal fauna (Murray, 1988). Although less affected, wind dispersal also declines in relation to forest edge distance (Holl, 1999). The predominance of a certain dispersion mechanism is related to the type of environment. In the study sites, we predicted a higher number of species dispersed by wind, since these areas were abandoned pastures, at the beginning of regeneration (Table 1), and also because visitation of dispersing fauna is infrequent or non-existent in this type of environment. Anemochory and autochory are typical of open environments, such as sites in the initial stages of succession (Tomazi et al., 2010; Guimarães et al., 2014).

In terms of differences within the soil profile (Table 2), the lower amount of seed in the first layer of the soil of area II in comparison with deeper layers was possibly due to soil turning. Tilling promoted 
the mixing of the soil layers, resulting in a more homogeneous distribution of the seeds throughout the soil profile. With the soil temporarily free of competition by the Urochloa grasses, there was probably greater germination of the seeds in the first layers, causing a reduction in the seed bank.

In area I, which did not undergo recent upheaval, seed distribution decreased as the soil layers deepened, showing a more than $50 \%$ seed reduction. Vertical seed distribution occurs due to the action of biotic and abiotic mechanisms of incorporation into the soil and as a result of the life span of the seeds of different species (Costa et al., 2013). The area at the initial regeneration stage (area III) did not show a significant difference between the depths, which suggests, although it has not been evaluated, a low incorporation of propagules into the seed bank of the first soil layer (0 to $3 \mathrm{~cm}$ ).

Low seed availability in pastures is a limiting factor for recruitment of native species (Harms et al., 2000). In addition to the other factors mentioned, the large biomass of grasses in the soil makes it difficult for allogeneic propagules to be incorporated into the seed bank. Thus, in pastures characterized by strongly inhibitory vegetation, greater efforts are required to induce natural regeneration. Methods to improve seed rain and seedbed improvement practices should be combined to overcome both dispersive and competitive barriers, without which native species will be unlikely to survive (Tomazi et al., 2010; Reid \& Holl, 2013).

\section{CONCLUSION}

The seed densities found in the present study are compatible with those of seed banks of anthropic landscapes. In the seed banks of the three areas, there were only a few seeds of a restricted number of woody species, which therefore represents a limited resource for forest regeneration purposes.

Although the seed bank consists of mainly herbaceous species, we also found important colonizing shrubs that facilitate natural regeneration.

\section{SUBMISSION STATUS}

Received: 9 aug., 2017

Accepted: 26 oct., 2017

\section{CORRESPONDENCE TO}

\section{Rosimeri de Oliveira Fragoso}

Departamento de Fitotecnia e Fitossanitarismo, Universidade Federal do Paraná - UFPR, Rua dos Funcionários, 1540, Juvevê, CP 19061, CEP 80035-050, Curitiba, PR, Brasil

e-mail:meri_ol@yahoo.com.br

\section{REFERENCES}

Bitencourt F, Zocche JJ, Costa S, Souza PZ, Mendes AR. Nucleação por Mimosa bimucronata (DC.) O. Kuntze em áreas degradadas pela mineração de carvão. Revista Brasileira de Biociências 2007; 5(1): 750-752.

Brower JE, Zar JH. Field and laboratory methods for general ecology. Lowa: Brown Publishers, 1984.

Budowski G. Distribution of tropical american rain forest species in the light of sucessional processes. Turrialba 1965; 15(1): 40-42.

Calegari L, Martins SV, Campos LC, Silva E, Gleriani JM. Avaliação do banco de sementes do solo para fins de restauração florestal em Carandaí, MG. Revista Árvore 2013; 37(5): 871-880. http://dx.doi.org/10.1590/S010067622013000500009 .

Carpanezzi AA. Fundamentos para a reabilitação de ecossistemas florestais. In: Galvão APM, Porfírio-da-Silva V, editores. Restauração florestal: fundamentos e estudos de caso. Colombo: Embrapa Florestas; 2005.

Carvalho PER. Espécies florestais brasileiras: recomendações silviculturais, potencialidades e uso de madeira. Colombo: Embrapa-CNPF; Brasília: Embrapa-SPI; 1994.

Chapla TE, Campos JB. Soil seed bank during succession at an abandoned pasture in the upper Paraná river-floodplain, Brazil. Acta Scientiarum 2011; 33(1): 59-69.

Chazdon RL, Harvey CA, Komar O, Griffith DM, Ferguson BG, Martínez-Ramos M et al. Beyond reserves: a research agenda for conserving biodiversity in human-modified tropical landscapes. Biotropica 2009; 41(2): 142-153. http:// dx.doi.org/10.1111/j.1744-7429.2008.00471.x.

Cheung KC, Marques MCM, Liebsch D. Relação entre a presença de vegetação herbácea e a regeneração natural de espécies lenhosas em pastagens abandonadas na Floresta Ombrófila Densa do Sul do Brasil. Acta Botanica Brasílica 2009; 23(4): 1048-1056. http://dx.doi.org/10.1590/S010233062009000400015 .

Costa JR, Mitja D, Leal Filho N. Bancos de sementes do solo em pastagens na Amazônia Central. Pesquisa Florestal Brasileira 2013; 33(74): 115-125. http://dx.doi. org/10.4336/2013.pfb.33.74.431.

Costalonga SR, Reis GG, Reis MGF, Silva AF, Borges EEL, Guimarães FP. Florística do banco de sementes do solo 
em áreas contíguas de pastagem degradada, plantio de eucalipto e floresta em Paula Cândido, MG. Floresta 2006; 36(2): 239-250. http://dx.doi.org/10.5380/rf.v36i2.6455.

Dias-Filho MB. Competição e sucessão vegetal em pastagens. Belém: Embrapa Amazônia Oriental; 2006. (Documentos; no. 240).

Gross KLA. Comparision of methods for estimating seed numbers in the soil. Journal of Ecology 1990; 78(4): 10791093. http://dx.doi.org/10.2307/2260953.

Guimarães S, Martins SV, Neri AV, Gleriani JM, Silva KA. Banco de sementes de áreas em restauração florestal em Aimorés, MG. Pesquisa Florestal Brasileira 2014; 34(80): 357-368. http://dx.doi.org/10.4336/2014.pfb.34.80.437.

Hall JB, Swaine MB. Seed stocks in Ghanaian forest soil. Biotropica 1980; 12(4): 256-263. http://dx.doi. org/10.2307/2387695.

Harms KE, Wright SJ, Calderón O, Hernández A, Herre EA. Pervasive density-dependent recruitment enhances seedling diversity in a tropical forest. Nature 2000; 404(6777): 493-495. http://dx.doi.org/10.1038/35006630. PMid:10761916.

Holl KD. Do bird perching structures elevate seed rain and seedling establishment in abandoned tropical pasture? Restoration Ecology 1998; 6(3): 253-261. http://dx.doi. org/10.1046/j.1526-100X.1998.00638.x.

Holl KD. Factors limiting tropical rain forest regeneration in abandoned pasture: seed rain, seed germination, microclimate, and soil. Biotropica 1999; 31(2): 229-242. http://dx.doi.org/10.1111/j.1744-7429.1999.tb00135.x.

Instituto Agronômico do Paraná - IAPAR. Cartas climáticas do Paraná [online]. Londrina: Paraná; 2015. [cited 2015 june 26]. Available from: http://www.iapar.br/modules/ conteudo/conteudo.php? conteudo=863

Instituto Brasileiro de Geografia e Estatística. Departamento de Recursos Naturais e Estudos Ambientais - IBGE. Manual técnico da vegetação brasileira. Rio de Janeiro: IBGE; 2012.

Ikeda FS, Mitja D, Vilela L, Carmona R. Banco de sementes no solo em sistemas de cultivo lavoura-pastagem. Pesquisa Agropecuária Brasileira 2007; 42(11): 1545-1551. http:// dx.doi.org/10.1590/S0100-204X2007001100005.

Jardim Botânico do Rio de Janeiro - JBRJ. Flora do Brasil 2020 em construção [online]. Rio de Janeiro: Jardim Botânico do Rio de Janeiro; 2015. [cited 2015 Aug. 10]. Available from: http://floradobrasil.jbrj.gov.br

Kissmann KG, Groth D. Plantas infestantes e nocivas. 2. ed. São Paulo: BASF; 1997.

Lanzanova ME, Nicoloso RS, Lovato T, Eltz FLF, Amado TJC, Reinert DJ. Atributos físicos do solo em sistema de integração lavoura-pecuária sob plantio direto. Revista Brasileira de Ciência do Solo 2007; 31(5): 1131-1140. http://dx.doi.org/10.1590/S0100-06832007000500028.
Leal N Fo, Sena JS, Santos GR. Variações espaço-temporais no estoque de sementes do solo na Floresta Amazônica. Acta Amazonica 2013; 43(3): 305-314. http://dx.doi. org/10.1590/S0044-59672013000300006.

Lopes KP, Souza VC, Andrade LA, Dornelas GV, Bruno RLA. Estudo do banco de sementes em povoamentos florestais puros e em uma capoeira de Floresta Ombrófila Aberta, no município de Areia, PB, Brasil. Acta Botanica Brasílica 2006; 20(1): 105-113. http://dx.doi.org/10.1590/ S0102-33062006000100010.

López-Toledo L, Martínez-Ramos M. The soil seed bank in abandoned tropical pastures: source of regeneration or invasion? Revista Mexicana de Biodiversidad 2011; 82(2): 663-678.

Lorenzi H. Plantas daninhas do Brasil: terrestres, aquáticas, parasitas e tóxicas. 4. ed. Nova Odessa: Instituto Plantarum; 2008.

Martins AM, Engel VL. Soil seed banks in tropical forest fragments with different disturbance histories in southeastern Brazil. Ecological Engineering 2007; 31(3): 165-174. http://dx.doi.org/10.1016/j.ecoleng.2007.05.008.

Miles JW, Valle CB. Brachiaria: biología, agronomía y mejoramiento. Cali: CIAT; 1998.

Miranda A No, Martins SV, Silva KA, Gleriani JM. Banco de sementes do solo e serapilheira acumulada em floresta restaurada. Revista Árvore 2014; 38(4): 609-620. http:// dx.doi.org/10.1590/S0100-67622014000400004.

Murray KG. Avian seed dispersal of three neotropical gap-dependent plants. Ecological Monographs 1988; 58(4): 271-298. http://dx.doi.org/10.2307/1942541.

Myers JA, Harms KE. Seed arrival, ecological filters, and plant species richness: a meta-analysis. Ecology Letters 2009; 12(11): 1250-1260. http://dx.doi.org/10.1111/j.14610248.2009.01373.x. PMid:19723285.

Pereira IM, Alvarenga AP, Botelho SA. Banco de sementes do solo, como subsídio à recomposição de mata ciliar. Floresta 2010; 40(4): 721-730. http://dx.doi.org/10.5380/ rf.v40i4.20324.

Reid JL, Holl KD. Arrival $\neq$ Survival. Restoration Ecology 2013; 21(2): 153-155. http://dx.doi.org/10.1111/j.1526100X.2012.00922.x.

Scheer MB, Gatti G, Wisniewski C, Mocochinski AY, Cavassani AT, Lorenzetto A et al. Patterns of litter production in a secondary alluvial Atlantic rain forest in southern Brazil. Revista Brasileira de Botanica. Brazilian Journal of Botany 2009; 32(4): 805-817. http://dx.doi. org/10.1590/S0100-84042009000400018.

Severino FJ, Carvalho SJP, Christoffoleti PJ. Interferências mútuas entre a cultura do milho, espécies forrageiras e plantas daninhas em um sistema de consórcio. III Implicações sobre as plantas daninhas. Planta Daninha 2006; 24(1): 53-60. http://dx.doi.org/10.1590/S010083582006000100007 . 
Silva DSM, Dias-Filho MB. Banco de sementes de plantas daninhas em solo cultivado com pastagens de Brachiaria brizantha e Brachiaria humidicola de diferentes idades. Planta Daninha 2001; 19(2): 179-185. http://dx.doi. org/10.1590/S0100-83582001000200004.

Silva JO, Fagan EB, Teixeira WF, Sousa MC, Silva JR. Análise do banco de sementes e da fertilidade do solo como ferramentas para recuperação de áreas perturbadas. Biotemas 2011; 25(1): 23-29.

Silva-Weber AJC, Nogueira AC, Carpanezzi AA, Galvão F, Weber SH. Composição florística e distribuição sazonal do banco de sementes em Floresta Ombrófila Mista Aluvial, Araucária, PR. Pesquisa Florestal Brasileira 2012; 32(70): 193-207. http://dx.doi.org/10.4336/2012.pfb.32.70.77.

Sparovek G, Barretto A, Klug I, Papp L, Lino J. A revisão do Código Florestal Brasileiro. Novos Estudos CEBRAP 2011; 89(89): 111-135. http://dx.doi.org/10.1590/S010133002011000100007 .

Thompson K, Grime JP. Seasonal variation in the seed banks of herbaceous species in ten contrasting habitats. Journal of Ecology 1979; 67(3): 893-921. http://dx.doi. org/10.2307/2259220.
Tomazi AL, Zimmermann CE, Laps RR. Poleiros artificiais como modelo de nucleação para restauração de ambientes ciliares: caracterização da chuva de sementes e regeneração natural. Biotemas 2010; 23(3): 125-135.

Tres DR, Sant'Anna CS, Basso S, Langa R, Ribas Júnior U, Reis A. Banco e chuva de sementes como indicadores para a restauração ecológica de matas ciliares. Revista Brasileira de Biociências 2007; 5(supl.): 309-311.

Van der Pijl L. Principles of dispersal in higher plants. New York: Springer-Verlag; 1982. http://dx.doi.org/10.1007/9783-642-87925-8.

Vieira CM, Pessoa SVA. Estrutura e composição florística do estrato herbáceo subarbustivo de um pasto abandonado na Reserva Biológica de Poço das Antas, município de Silva Jardim, RJ. Rodriguésia 2001; 52(80): 17-30. http:// dx.doi.org/10.1590/2175-78602001528002.

Wijdeven SMJ, Kuzee ME. Seed availability as a limiting factor in forest recovery processes in Costa Rica. Restoration Ecology 2000; 8(4): 414-424. http://dx.doi. org/10.1046/j.1526-100x.2000.80056.x. 